\title{
GENDER KETIGA DAN TRANSPHOBIA SEBUAH DUNIA BARU
}

\author{
Gefarina Djohan \\ Universitas Islam Negeri (UIN) Syarif Hidayatullah Jakarta \\ E-mail: gefarina.djohan@gmail.com
}

\begin{abstract}
Abstrak: Judul diatas menjadi tidak umum manakala kita diperhadapkan pada istilah gender yang masih membutuhkan penjelasan panjang di tengah-tengah masyarakat. Ketika seorang kepala daerah dalam pidatonya menyebutkan pada sekelompok perempuan dengan sebutan yang manis "wahai para gender", lantas semua orang mengasumsikan bahwa gender itu adalah perempuan. Benarkah gender itu berarti perempuan? Ternyata jawaban berdasarkan kajian ilmiah, gender tidak bisa diasumsikan sebagai perempuan melainkan gender adalah konsep yang merujuk pada perbedaan antara laki-laki dan perempuan yang dikonstruksikan secara sosial, dapat berubah-ubah dengan berlalunya waktu, sangat bervariasi di dalam dan antara budaya. Berbeda dengan kodrat dalam kaitannya dengan penciptaan, maka mahluk di dunia ini terdiri atas perempuan dan laki-laki. Perempuan mempunyai ovum, menstruation, melahirkan dan menyusui, sedangkan laki-laki mempunyai sperma dan penis. Cara pandang yang berlandaskan pada kultur, nilai dan norma-norma tertentu melahirkan kontruksi sosial yang kemudian menempatkan bahwa perempuan itu lemah, feminim, reproduksi, berperan di domestik dan pencari nafkah tambahan, sedangkan laki-laki kuat, maskulin, bekerja di ruangan publik dan pencari nafkah utama. Meskipun pandangan ini tidak semuanya bisa diterima, tetapi masyarakat seolah-olah meyakini sebagai sebuah kebenaran. Konstruksi sosial inilah yang kemudian memunculkan situasi ketidak adilan gender diantaranya perempuan subordinasi laki-laki, pelebelan, doble burden, marginalisasi, kekerasan dan kemiskinan. Jika dikemudian hari muncul fenomena tuntutan untuk "gender ke tiga" adalah situasi yang berbeda. Gender ke tiga dimaksud adalah gejala transseksualisme ataupun transgender yaitu merupakan suatu gejala ketidakpuasan seseorang karena merasa tidak adanya kecocokan antara bentuk fisik dan kelamin dengan kejiwaan ataupun adanya ketidak puasan dengan alat kelamin yang dimilikinya. Pada hakikatnya hal ini adalah masalah kebingungan jenis kelamin. Konon kaum transgender ini seringkali mengalami segala bentuk kekerasan dan diskriminasi, namun muncul pula pertanyaan besar apakah dengan melegalisasikan gender ketiga menjadi solusi terbaik? Rasa ketidaksukaan terhadap eksistensi transgender (Transphobia) kemudian menjadi fenomena umum yang terus bergulir seiring dengan perjalanan waktu dan derasnya arus globalisasi, sehingga masalah yang muncul menembus batas wilayah di tingkat lokal, nasional, regional maupun internasional.
\end{abstract}

Kata kunci : Gender, Transgender. Gender ke Tiga dan Transphobia

\section{PENDAHULUAN}

Transgender adalah manusia dengan orientasi seksual, identitas dan ekspresi gender yang berbeda dari konstruksi mainstream masyarakat Indonesia pada umumnya. Adapun Secara etimologi transgender berasal dari dua kata yaitu "trans" yang berarti pindah (tangan; tanggungan); pemindahan dan "gender" yang berarti jenis kelamin. Sedangkan istilah lain yang digunakan dalam operasi pergantian kelamin ialah "transseksual" yaitu merupakan terjemahan dari Bahasa Inggris. Secara terminologi transgender atau transseksual diartikan dengan suatu gejala ketidakpuasan seseorang karena merasa tidak adanya kecocokan antara bentuk 
fisik dan kelamin dengan kejiwaan, atau adanya ketidakpuasan dengan alat kelamin yang dimilikinya. Beberapa ekspresi yang dapat dilihat ialah bisa dalam bentuk dandanan (make up), gaya dan tingkah laku, bahkan sampai kepada operasi penggantian kelamin (Mahjuddin, 2005: 25). Lebih lanjut dapat dijelaskan bahwa munculnya transgender atau transeksual adalah akibat dari adanya faktor bawaan (hormon dan gen) akibat dari lemahnya rangsangan pembentukan jenis kelamin (Gunawan Kosasih,tt : 8) dan faktor lingkungan yaitu perubahan dalam keadaan biologik sekelilingnya seperti pendidikan yang salah pada masa kecil dengan membiarkan anak laki-laki berkembang dalam tingkah laku perempuan, pada masa pubertas dengan homoseksual yang kecewa dan trauma, trauma pergaulan seks dengan pacar, suami atau istri. Hal-hal ini dapat mengakibatkan differensiasi yang tidak sempurna dari tingkat yang ringan sampai yang berat. Bahkan pada situasi terakhir ini tidak jarang seseorang kemudian berkeinginan mengganti jenis kelamin apakah dari laki-laki menjadi perempuan dan sebalik perempuan menjadi lakilaki. Pergantian status jenis kelamin seseorang yang disebut transseksual cukup marak dimana seseorang secara fisik sehat dan sempurna sebagai pria atau wanita, akan tetapi ia secara psikis mempunyai kecenderungan yang amat kuat ingin mengekspresikan diri serta menampilkan diri sebagai lawan jenisnya, sehingga hal inilah kemudian timbul motivasi yang kuat untuk melakukan pergantian kelamin. Keinginan penderita untuk menjalani operasi kelamin lebih didominasi untuk kesesuaian kondisi fisik dan jiwa, sehingga dapat menempatkan diri dan diterima masyarakat sebagai orang yang utuh. Operasi penyesuaian sebagaimana disebutkan diatas, dilihat dari segi teknis pelaksanaannya termaksud dalam teknologi transplantasi. Oleh karena itu penanganannya memerlukan pengaturan hukum yang ketat dengan mempertimbangkan nilai-nilai sosial budaya dan agama yang hidup dalam masyarakat. Perubahan status seseorang yang dikenal dengan istilah penggantian kelamin (Ahmad Ramali, 1989: 205), ditinjau dari segi hukumnya merupakan sesuatu yang sangat besar pengaruhnya terhadap perkembangan didalam masyarakat karena peristiwa perubahan status ini merupakan persoalan baru dalam masyarakat, selanjutnya ternyata hal ini belum diatur oleh undang-undang, karena pembuat undangundang waktu itu tidak atau belum memperkirakan terjadinya hal-hal seperti itu. Demikian pula di dalam hukum ternyata diperlukan suatu penegasan status seorang wanita atau laki-laki, karena penentuan status demikian itu diperlukan baik dalam hukum perdata misalnya apabila seseorang akan menikah, dalam hal warisan, dalam perjanjian kerja dan lain-lain maupun dalam hukum pidana dan peraturan hukum perundang-undangan hanya mengenal istilah laki-laki atau perempuan.

\section{PEMBAHASAN}

\section{Fenomena Gender Ketiga dan Transphobia}

Gender ketiga dan transphobia adalah sebuah fenemomena dimana masyarakat secara meluas menolak dengan sikap atau tindakan yang takut atau memberikan label negatif kepada individu maupun kelompok atas dasar orientasi seksual dan identitas gender seseorang seperti homoseksual (gay,lesbian), biseksual maupun transgender. Kemudian tindakan transphobia ini dituangkan dalam bentuk kata, kalimat, media maupun cara berpikir. Hal ini bisa dimengerti jika melihat kenyataan kelompok seperti lesbi, gay, biseksual, dan transgender (LGBT) yang dulunya tidak terlalu populer kini, geliatnya terlihat mewabah hampir di seluruh kota besar di Indonesia, bahkan di seluruh dunia Dalam kaitan tersebut Organisasi Kesehatan Dunia (WHO) tanggal 17 Mei 1990 telah memutuskan transgender sebagai gangguan kejiwaan (bukan penyakit). Putusan itu 


\section{4-61 | HARKAT: Media Komunikasi Islam Tentang Gender dan Anak, 11 (1), 2015}

berdasarkan putusan dari Asosiasi Psikologi/Psikiatri di seluruh dunia, yang sudah mengeluarkan transgender sebagai gangguan kejiwaan. Sedangkan di Indonesia melalui Pedoman Penggolongan Diagnosa Gangguan Jiwa (PPDGJ) III tahun 1993, Kementerian Kesehatan RI juga sudah mengeluarkan homoseksual-transgender sebagai gangguan kejiwaan. Seiring dengan penegasan keputusankeputusan diatas transphobia atau penolakan terhadap keberadaan transgender juga tidak bisa dianggap sederhana sebagian mereka menganggap ada ketersumbatan komunikasi politik yang selama ini dianggap meminggirkan kaum LGBT, dan keinginan yang kemudian muncul untuk memperjuangkan agar mendapat pengakuan dan melegalkan pada saat mereka ingin disyahkan dalam ikatan perkawinan. Golongan LGBT ini menggeliat dan kian mendapat tempat di seluruh dunia. Tercatat sudah 14 negara di dunia yang melegalkan pernikahan sesama jenis. Pernikahan sesama jenis pertama kali dilegalkan di Belanda, pada 2001. Menyusul Kanada, Afrika Selatan, Belgia, dan Spanyol. Kemudian Argentina, Denmark, Islandia, Norwegia, Portugal, dan Swedia serta terakhir Perancis. Di Amerika Serikat, perdebatan soal perkawinan sejenis belum sampai ke level Mahkamah Agung dan masih terus dikembangakan. Namun ada sekitar 12 negara bagian dan District of Columbia (DC) di Amerika telah melegalisasi pernikahan sesama jenis. Akan tetapi ada juga Negara-negara yang menganggap LGBT sebagai kriminal yaitu Russia, Uganda, dan Macedonia. Sisanya, sebanyak 78 negara lebih termasuk negara negara berpenduduk Islam seperti, negara-negara Timur Tengah, Indonesia, Brunai dan Malaysia tidak mempunyai undang-undang anti LGBT sehinggga negara-negara tersebut bisa dianggap negara yang membolehkan LGBT, walaupun tidak melegalkan pernikahan sesama jenis.

Kaum transgender memiliki suatu ketidakpuasan terhadap dirinya sendiri karena merasa tidak adanya kecocokan antara bentuk fisik dan kelamin dengan kejiwaan. Ekspresi orang yang mengalami kebingungan jenis kelamin ini bisa terlihat dalam bentuk dandanan, gaya bicara, tingkah laku, bahkan sampai kepada keinginan untuk melakukan operasi penggantian kelamin (Sex Reassignment Surgery). Meskipun demikian para ahli menyebutkan bahwa operasi pergantian kelamin tidak bisa dilakukan oleh sembarang orang dengan mudah. Untuk dapat dilakukan operasi perubahan kelamin, di Indonesia sesuai standar IDI harus didahului oleh observasi oleh Tim Dokter yang meliputi tes psikologi, tes hormonal, tes kepribadian, tes kesehatan yang dilakukan oleh ahli-ahli seperti Psikiater, Psikolog, Bedah, Penyakit Dalam, Genetikal, Obstetry dan Ginecology, setelah melalui serangkaian tes barulah seseorang dapat melakukan operasi perubahan. Operasi kelamin bisa digolongkan termasuk dalam operasi bedah plastik dan rekonstruksi organ tubuh. Menurut Undang-Undang Republik Indonesia Nomor 23 Tahun 1992 Tentang kesehatan Pasal 37 ayat (2) bedah plastik dan rekonstruksi tidak boleh bertentangan dengan norma yang berlaku dalam masyarakat. Norma yang dimaksud dalam penjelasan Undang-Undang Republik Indonesia Nomor 23 Tahun 1992 Tentang kesehatan Pasal 37 ayat (2) adalah norma hukum, agama, kesusilaan dan kesopanan, sedangkan dalam norma hukum tidak ada aturan mengenai transgender. Begitu pula norma agama, dalam norma agama Islam contohnya, para ulama fiqih mendasarkan ketetapan hukum tersebut pada dalil-dalil yaitu Hadits Nabi SAW, "Allah mengutuk laki-laki yang menyerupai wanita dan wanita yang menyerupai laki-laki." (HR. Ahmad). Dalam norma kesusilaan dan kesopanan, masalah transgender atau kebingungan jenis kelamin masih dianggap sesuatu yang aneh dan selalu mendapat cemooh dan hinaan dari masyarakat. Bedah plastik atau rekonstruksi dalam penjelasan Pasal 37 ayat (2) Undang-Undang Nomor 23 Tahun 1992 
tentang Kesehatan adalah suatu tindakan medis yang dilakukan untuk memulihkan keadaan fisik seseorang dalam kondisi tubuhnya termasuk bedah plastik kosmetika dan estetika.

Perbedaan orientasi seksual seperti lesbian, gay, biseksual, transgender, interseksual (LGBTI) muncul sebagai sebuah fenomena dimana pelanggaran hak-hak kelompok yang justru ironinya seolah-olah dibiarkan saja terjadi. Bentuk pelanggaran haknya bermacam-macam, namun sejauh ini kita hanya bisa membatasi pada tindakan stigmatisasi, diskriminasi dan kekerasan. Pembatasan itu lebih disebabkan karena ketiga tindakan itu dinilai sebagai pelanggaran hak-hak pokok yang dialami oleh sebagian besar kelompok LGBTI, baik di Indonesia, maupun di sebagian besar negara di dunia. Ketiga tindakan itu kemudian menimbulkan pelanggaran hak-hak kelompok LGBTI yang lebih kompleks, baik yang dilakukan oleh pemerintah maupun masyarakat. Pada akhirnya semua pelanggaran hak-hak kelompok LGBTI itu akan mempengaruhi seluruh sendi kehidupan individu-individu LGBTI itu sendiri.

Konon perlakuan tidak manusiawi serta kekerasan fisik adalah makanan sehari-hari. Pada tahun 2011, "AY" ditembak di Menteng, Jakarta. Hasil otopsi menunjukkan AY ditembak dari jarak sedekat 1 meter dan dipukul di bagian dada. Dicurigai ia ditembak oleh seorang petugas kepolisian atau seseorang yang masih berhubungan dengan polisi. Kasus ini telah dilaporkan ke kepolisian Menteng tetapi masih tidak ada informasi dan tindak lanjut hingga saat ini. Bella, Robin, dan AY memiliki sebuah kesamaan yang mengantarkan mereka pada perlakuan tidak manusiawi. Apakah mata rantai dari ketiga kasus tersebut? Bella, Robin dan AY adalah "berbeda". Mereka memiliki orientasi seksual, identitas dan ekspresi gender yang berbeda dari konstruksi mainstream masyarakat Indonesia. Bella adalah seorang lesbian. Robin adalah seorang pria gay. Dan AY adalah seorang waria. Apa yang mereka alami adalah contoh dari diskriminasi berdasarkan orientasi seksual dan gender.

Secara definisi, seorang lesbian adalah perempuan yang tertarik terhadap sesama perempuan. Pria gay adalah pria yang tertarik kepada sesama pria. Seorang biseksual adalah orang tertarik pada individu sesama jenis atau berbeda jenis. Seorang transgender adalah orang yang identitas psikologisnya (identitas gender) berbeda dengan ekspektasi sosial terhadap fisik jenis kelamin yang ia miliki sejak lahir. Diskriminasi dan kekerasan bisa datang dari keluarga, masyarakat, atau aparat negara. Sejauh ini masyarakat masih memandang bahwa LGBT adalah manusia yang menyimpang, bersalah, pendosa, yang terendah dari yang terendah. Pandangan ini mengembangkan sebuah pandangan lagi bahwa praktik untuk memperlakukan LGBT dengan kejam, tidak manusiawi, merendahkan martabat manusia pantas dilakukan.

Selain itu tidak mudah bagi transgender untuk mendapatkan pekerjaan jika penampilan mereka tidak sesuai dengan gender sejati mereka. Seorang transgender sering harus mengubah penampilan mereka agar bisa bekerja, bahkan di tempat seperti salon kecantikan sekalipun. Pada kasus lain, seorang transgender terpaksa mengundurkan diri dari posisi mengajar karena diskriminasi yang diterima makin tak tertahankan. Kasus lainnya meliputi cacian, intimidasi, dipermalukan di muka umum (seperti ditelanjangi), atau diusir dari tempat tinggal atau desa hingga dilempari dengan batu oleh masyarakat (kasus pada awal tahun 2013 di Jakarta yang telah dilaporkan ke Komisi Nasional Hak Asasi Manusia). Orientasi dan gender nonheteroseksual sering dicap sebagai menyimpang, dan ini dianggap sebagai produk dari budaya Barat yang telah menodai budaya luhur Indonesia. Meskipun anggapan ini tentu saja 


\section{6-61 | HARKAT: Media Komunikasi Islam Tentang Gender dan Anak, 11 (1), 2015}

tidak sepenuhnya benar, karena pada kenyataannya pada model kearifan lokal sukusuku tertentu di Indonesia sudah nenahami adanya perbedaan tersebut yang dimaksud adalah gender ke tiga. Masyarakat Bugis misalnya sudah mengenal calalai (perempuan maskulin), calabai (lelaki feminin), dan bissu (pendeta dengan kombinasi sifat keempat gender yang ada). Di Ponorogo pada seni tradisional reyog ada gemblakan biasanya gemulai berhubungan dengan warok atau warokan. Praktik hubungan seksual sejenis bahkan telah mempunyai istilah dalam bahasa Jawa di masa lampau, yaitu jinambu (pasif) dan anjambu (aktif). Begitu juga pada kesenian indang di Sumatra Barat, para penarinya adalah remaja lelaki yang gemulai yang biasanya tidur bersama dengan manajer grup itu. Gambaran tentang penderitaan yang dialami oleh kaum LGBT tidaklah serta merta menimbulkan simpati yang berlebihan dari masyarakat secara umum, tetap saja kehadiran mereka menjadi stigma buruk yang dianggap sebagai cikal bakal dari bentuk-bentuk kerawanan sosial dan kecenderungan mengganggu ketertiban umum. Fakta tentang keberagaman budaya sebagaimana dijelaskan diatas yang mengindikasikan bahwa masyarakat Indonesia pluralistis sehingga kaum LGBT juga harus diberi tempat untuk hidup bebas tanpa adanya diskriminasi. Namun, pada kenyataannya individu LGBT Indonesia tetap menghadapi posisi sulit. Realita ini menambah tekanan ke banyak pribadi LGBT untuk makin bersembunyi. Menelan stigma negatif dari masyarakat menjadi stigma ke diri sendiri (selfstigma). Sebuah lingkaran setan yang semakin menjauhkan mereka dari pemenuhan hak asasi sebagai manusia. Manusia terlahir dengan hak asasi, semua orang memilikinya. Hak bersifat universal: laki-laki dan perempuan, hitam dan putih, relijius dan non-relijius. Hak dimiliki oleh semua orang secara setara. Hak ditentukan oleh kebutuhan manusia untuk membuat hidupnya bermakna dan sangat penting untuk menjaga kita tetap merasa hidup. Hak menjadi sangat berharga ketika hilang. Hak adalah tuntutan Anda terhadap orang lain sejauh dalam menggunakan hak, Anda tidak menghentikan orang lain menjalankan haknya.

Lantas bagaimana dengan hak yang yang terkait dengan heteroseksual dan homoseksual, transgender dan non-transgender, apakah ini termasuk ketegori hak azasi manusia yang harus dipenuhi oleh Negara RI. Dalam konteks Negara RI, setiap individu LGBT yang hidup di Indonesia merupakan warga Negara Indonesia (WNI) yang sah. Sesuai dengan hukum hak-hak manusia Internasional, Pemerintah RI harus taat kepada Deklarasi Universal Hak Asasi Manusia (DUHAM) dan semua kovenan internasional tentang hak-hak manusia yang telah diratifikasi oleh pemerintah RI. Beberapa kewajiban pokok dari pemerintah adalah mengakui, mempromosikan, memenuhi, dan melindungi hak-hak warga negaranya serta menghukum setiap pelaku pelanggaran hak sesuai dengan hukum hak-hak manusia internasional. Dan dikarenakan orang-orang LGBT juga adalah WNI, maka pemerintah RI tidak dapat membiarkan pelanggaran hak terhadap orangorang LGBT terjadi di Indonesia atas dasar apapun. Kemudian pemerintah RI harus merumuskan produk hukum untuk menjerat dan menghukum semua pelaku pelanggaran hak-hak manusia, termasuk juga pelanggaran hak-hak kelompok LGBT.

\section{LGBT dalam Perspektif HAM dan Undang- Undang}

Masyarakat heteroseksual adalah sebuah masyarakat yang menjadi kebalikan dari kaum homoseksual, sebab mereka berpasangan dengan lawan jenis. Homoseksual dan sejenisnya menumbuhkan rasa benci dan akhirnya berujung pada tindak diskriminasi. Sementara masyarakat homoseksual sendiri menggunakan istilah gay, lesbian, dan queer sebagai penunjuk makna 
positif dan suportif, juga digunakan dalam diskursus yang lebih luas. Pada tahun 1950-an, gelombang perjuangan komunitas LGBTI masuk pada arena menolak pemampatan sosial terhadap komunitas mereka yang hanya dipandang dalam area seksualitasnya. Pada masa ini, mereka cenderung lebih nyaman menggunakan istilah homophile daripada istilah homoseksual. Sebagaimana yang biasa kita kenal selama ini. Homophile bermakna mencintai sejenis (love to same sex) sehingga ia tidak melulu berkonotasi pada seks. Akan tetapi, dalam perkembangan wacana dan aksi perjuangan saat ini, komunitas LGBTI sedang menuju pada aras perjuangan di ruang hak seksual dan pengakuan atas keragaman seksual. Asumsi dan argumen yang digunakan dengan mendorongkan semangat dan pengakuan atas keragaman seksual adalah bahwa manusia tidak memiliki identitas dan orientasi seksual yang tunggal. Karenanya, tidak ada satu kategori seksual yang bisa mengklaim sebagai yang "paling normal". Dengan demikian, perjuangan ini mengarah pada pengakuan tentang kenormalan lewat perjuangan persamaan hak dan kedudukan baik dalam konteks aturan hukum maupuan dalam konteks relasi sosial dengan mereka yang selama ini berorientasi heteroseksual. Hak seksual adalah alat dan tujuan perjuangan komunitas LGBTI.

Pertanyaannya, dari perspektif hak asasi manusia, adalah apakah semua kekhasan dan ciriciri itu dapat menjadi argumen untuk menuntut keadilan dan pemenuhan hak? Penyebutan hak dalam konteks hak asasi manusia tidak perlu dibarengi dengan pengertian kewajiban sehingga menjadi hak dan kewajiban asasi manusia. Di dalam pengertian hak asasi manusia, hak tersebut melekat pada manusia dan hanya dapat dimiliki oleh individu sedangkan kewajiban merupakan bagian simetri di atas negara, karena hanya negara-lah yang mempunyai kekuasaan memelihara dan melindungi hak-hak individu tersebut. Dengan demikian istilah "hak dan kewajiban asasi manusia” harus dimaknai sebagai berikut: hak ada pada individu sedangkan kewajiban ada pada pemerintah-negara, sehingga hak asasi manusia pada individu menimbulkan kewajiban pada pemerintah/negara untuk melindungi individu tersebut terhadap setiap kemungkinan pelanggaran termasuk pelanggaran dari negara atau aparat pemerintah sendiri. Dalam konteks Indonesia, secara konstitusional tanggung jawab untuk melakukan perlindungan dan penegakan hak asasi manusia berada pada negara, terutama pemerintah. Hal tersebut dapat dijumpai ketentuannya dalam Pasal 28I ayat (4) UUD 1945 yang berbunyi: "Perlindungan, pemajuan, penegakan, dan pemenuhan hak asasi manusia adalah tanggung jawab negara, terutama pemerintah". Selanjutnya Pasal 28I ayat (5) UUD 1945 menyebutkan bahwa untuk menegakkan dan melindungi hak asasi manusia sesuai dengan prinsip negara hukum yang demokratis, maka pelaksanaan hak asasi manusia dijamin, diatur dan dituangkan dalam peraturan perundang- undangan.4 Ketentuan di atas diperkuat dengan Undang-Undang Nomor 39 Tahun 1999 tentang Hak Asasi Manusia. Pasal 8 Undang-Undang tersebut menegaskan bahwa "Perlindungan, pemajuan dan penegakan hak asasi manusia terutama menjadi tanggung jawab pemerintah". Pemerintah yang dimaksud tentunya mencakup pengertian pemerintah pusat maupun pemerintah daerah. Bahkan pengertian pemerintah juga harus diperluas ke dalam pengertian eksekutif, legislatif dan yudikatif serta penyelenggara negara lainnya. Selain pemerintah, Pasal 100 Undang-Undang ini juga menentukan bahwa "setiap orang, kelompok organisasi politik, organisasi masyarakat, lembaga swadaya masyarakat atau lembaga kemasyarakatan lainnya berhak berpartisipasi dalam perlindungan, penegakan dan pemajuan hak asasi manusia”. Kewajiban Negara Sebagai konsekuensi dari corak relasi yang diatur dalam hukum hak asasi manusai internasional, negara memegang kewajiban-kewajiban tertentu dalam rangka merealisasikan hak-hak asasi manusia. Ada 


\section{8-61 | HARKAT: Media Komunikasi Islam Tentang Gender dan Anak, 11 (1), 2015}

beberapa macam kewajiban negara, di antaranya ialah 'kewajiban generik' dan 'kewajiban berbuat serta mencapai hasil dengan penjelasannya sebagai berikut:

(1) Kewajiban Generik Kewajiban ini disebut kewajiban generik karena kewajiban ini menjadi sumber bagi kewajiban-kewajiban lainnya. Pada dasarnya terdapat 3 (tiga) kewajiban generic yang antara lain meliputi (a) kewajiban menghormati (obligation to respect); (b) kewajiban melindungi (obligation to protect); dan (c) kewajiban memenuhi (obligation to fulfill). Kewajiban menghormati mengharuskan negara untuk tidak melakukan tindakan tertentu. Jika tindakan itu dilakukan, maka negara dikatakan telah melakukan pelanggaran hak asasi manusia. Oleh karena kewajiban ini mengharuskan negara untuk absen dari tindakan, maka kewajiban ini dikenal sebagai kewajiban negatif. Contoh dari kewajiban ini misalnya, negara -melalui aparatnya- tidak boleh melakukan penyiksaan untuk mengorek keterangan atau memaksa seseorang untuk mengaku telah melakukan suatu tindak pidana yang disangkakan. Kewajiban melindungi mengharuskan negara untuk mengambil tindakan tertentu guna melindungi hak asasi seseorang dari kemungkinan pelanggaran oleh orang lain atau oleh pihak non-negara. Tindakan untuk melindungi hak asasi manusia hak asasi manusia seseorang dari kemungkinan pelanggaran oleh pihak non-negara ini dikenal sebagai efek horisontal hak asasi manusia (horizontal effect of human rights). Oleh karena kewajiban ini mengharuskan negara untuk mengambil tindakan tertentu maka ia dikenal sebagai kewajiban positif. Kewajiban memenuhi merupakan kewajiban positif lainnya yang mengharuskan negara untuk menempuh langkah-langkah bagi pemenuhan hak asasi manusia. Contoh dari kewajiban ini misalnya dengan mengalokasikan anggaran pendidikan, membuat program pendidikan guru atau membangun gedung-gedung sekolah. Dalam konteks 'kewajiban memenuhi' perlu diingat bahwa kebebasan (freedom), karena sifatnya, tidak dapat dipenuhi. Negara tidak dapat dan tidak boleh memaksa seseorang untuk berpikir atau berkeyakinan tertentu. Namun kebebasan bisa difasilitasi dan dimajukan. Oleh karenanya, ditambahkan kategori ke-empat pada kewajiban generik, yakni kewajiban memajukan (obligation to promote).

(2) Kewajiban Berbuat Serta Mencapai Hasil Kewajiban berbuat dan kewajiban mencapai hasil akan memperjelas dimana posisi negara. Hal itu dapat dijelaskan sebagai berikut. Dalam rangka memenuhi kewajiban mencapai hasil (obligation of result), negara dituntut untuk membuat suatu kebijakan atau program agar setelah jangka waktu tertentu tidak ada lagi anak yang bekerja di sektor-sektor pekerjaan terburuk (worst forms of child labour). Hal ini dikatakan sebagai komitmen untuk mencapai hasil dan dalam rangka mencapai hasil sebagaimana dimaksud negara wajib melakukan tindakantindakan tertentu sekaligus tidak boleh melakukan tindakan-tindakan lainnya. Inilah yang disebut dengan kewajiban berbuat (obligation of conduct).

LGBTI dalam Aturan Hukum dan Hak Asasi Manusia sebagian besar berkaitan dengan isu seksualitas dan bagaimana respon masyarakat atau individu terhadap konsep seksualitas. Beberapa aspek jika didetailkan minimal akan menghasilkan daftar aspek hukum yang mengatur komunitas LGBTI, yakni: a. Peraturan tentang hak asasi manusia yang mengatur anti diskriminasi berbasis orientasi seksual dan identitas gender; Pengakuan hukum atas pernikahan sesama jenis; Hukum adopsi bagi komunitas LGBTI; Hukum bagi tindakan kejahatan dan kekerasan terhadap komunitas LGBTI; Hukum terkait sodomi; Hukum yang mengatur batas usia untuk memiliki kuasa pilihan untuk berhubungan seksual (age of sexual consent); Hukum donasi sperma \& inseminasi 
buatan (assisted reproduction); Dengan melihat aspek-aspek di atas, maka sesungguhnya akan sulit untuk melakukan proses generalisasi status hukum komunitas LGBTI di satu negara. Misalnya, di Indonesia belum ada aturan yang secara tekstual melarang bagi orang untuk memiliki orientasi seksual sesama jenis. Dengan demikian, susah untuk disimpulkan bahwa Indonesia adalah negara yang melarang homoseksualitas. Meski demikian fakta hukumnya, tindak kekerasan kerap terjadi terhadap komunitas LGBTI. Belum juga ada hukum yang melindungi mereka dari tindak kekerasan tersebut. Oleh karena itu, analisis status hukum terhadap komunitas LGBTI banyak dilakukan dengan melakukan proses kategorisasi aspek hukum sebagaimana daftar di atas.

Pelanggaran Hak Asasi Manusia Terhadap LGBTI di Indonesia dikaitkan dengan kekerasan Terhadap Komunitas LGBTI. Pelanggaran hak asasi manusia ini terjadi dalam banyak cara dan bentuk, dari penolakan atas hak hidup, hak untuk terbebas dari penyiksaan, keamanan pribadi, sampai pada diskriminasi ,. Ketidakadilan lainya adalah dalam bentuk yang mikro dengan dikeluarkan dari rumah dan tidak diakui sebagai bagian keluarga sampai ada ketidakadilan terhadap martabat dan kedaulatan sebagai individu, seperti pemaksaan untuk tetap diam walau pelecehan dan kekerasan terus mendera mereka. Situasi sosial seperti inilah yang umumnya terjadi di Indonesia. Kondisi ini diperparah ketika kelompok LGBTI dianggap sebagai ancaman pada saat "mempublik". Fakta-fakta kekerasan ini jelas sekali menggambarkan bagaimana negara turut andil dalam pembiaran untuk terjadinya tindak kekerasan. Dalam konteks hak asasi manusia, kekerasan ini dikategorikan sebagai pelanggaran by omission (pelanggaran karena pembiaran).

Banyak sumber yang menulis bahwa Indonesia tidak memiliki perangkat hukum yang melarang LGBTI. Satu-satunya rujukan hukum yang bisa diinterpretasikan secara luas untuk mengatur perilaku sesama jenis adalah KUHP Pasal 292 sebagai berikut: Orang dewasa yang melakukan perbuatan cabul dengan orang lain sesama kelamin, yang diketahuinya atau sepatutnya harus diduganya belum dewasa, diancam dengan pidana penjara paling lama lima tahun. Pasal 292 KUHP ini mensyaratkan korban harus berumur kurang dari 21 tahun dan belum menikah. Pemahaman terhadap pasal ini sangat penting mengingat ketentuannya masih tetap berlaku sebagai aturan hukum nasional. Pengaturan tentang delik kesusilaan di dalam KUHP menggolongkan jenis tindakan pidana kesusilaan ke dalam tindak pidana kesusilaan dengan jenis "kejahatan", yaitu dalam Bab XIV Buku II Pasal 281 sampai dengan Pasal 303 dan tindak pidana kesusilaan dengan jenis "pelanggaran”, yaitu Bab VI Buku III Pasal 532 sampai dengan 547 KUHP. Jika dilihat dari redaksi pasal yang ada, pasal ini tidaklah mencakup keseluruhan bentuk hubungan seksual sesama jenis. Pasal ini semata mengatur hubungan sesama jenis di mana pelaku adalah orang dewasa, dan korban adalah belum dewasa. Dengan makna literal tersebut, maka pasal tersebut lebih tepat dikatakan mengatur tindak 'sodomi' dibandingkan mengatur hubungan sesama jenis. Robot Gedek dan terakhir kasus sodomi Babe, untuk menyebut beberapa kasus yang menghebohkan, adalah jenis tindak kejahatan kesusilaan yang sudah terjadi di pelaksanaan hukum pidana di Indonesia. Dan dari hasil persidangan kedua terpidana, tidak ada dokumen pemeriksaan dalam proses pengadilan bahwa keduanya disebutkan berorientasi seksual sesama jenis. Orientasi seksual dalam resolusi tentang melawan eksekusi ekstra-yudisial (menghukum orang tanpa proses pengadilan) serta membolehkan hukuman mati atas dasar orientasi seksual. Ada 93 negara mendukung memasukkan kembali orientasi seksual ke dalam resolusi tersebut, 55 negara menentang dan 27 
negara abstain. Sebelumnya telah terjadi voting pertama dan terjadi perdebatan antara negara yang mendukung untuk dimasukan dengan negara yang menolaknya. Indonesia menjadi salah satu dari 55 negara yang menolak memasukan kata orientasi seksual didalam resolusi tersebut. Sehingga Indonesia tidak mendukung affirmative action atau perlindungan khusus bagi kelompok LGBTI.

Survey demografis dalam menghitung atau memperkirakan atau melakukan estimasi jumlah komunitas LGBTI belum pernah dilakukan di Indonesia. Satu-satunya estimasi yang pernah dilakukan untuk memperkirakan populasi LGBTI adalah estimasi yang dilakukan dalam kerangka penanggulangan HIV dan AIDS. Gerakan gay dan waria masuk ke dalam lingkaran penanggulanan HIV dan AIDS, maka secara langsung atau tidak langsung, ada beberapa titik kritis dan dalam jangka panjang dapat merugikan bagi komunitas gay dan waria. Minimal ada 3 alasan untuk mendukung analisis ini, yakni : Pertama, stigma bahwa mereka adalah kelompok penduduk yang memiliki masalah terkait HIV dan AIDS semakin kuat tertancap.

\section{PENUTUP}

Catatan Penutup dalam tulisan ini menggaris bawahi beberapa fakta buram bagi komunitas LGBTI di Indonesia. Di sini, ada 2 (dua) konteks makna buram yang bisa dijelaskan sebagai berikut : Pertama, buram dalam arti konotatif, berarti bahwa perjuangan komunitas LGBTI dalam mendapatkan pengakuan identitas dan hak seksual mereka masih harus berhadapan dengan situasi hukum nasional yang "sangat melarang" bagi identitas seksual dan gender komunitas LGBTI. Lahirnya beberapa UU atau peraturan daerah yang semakin menempatkan komunitas LGBTI sebagai 'abnormal' dan bahkan 'kriminal' adalah bukti yang sulit dibantah. Kedua, buram dalam makna denotatif, berarti fakta komunitas LGBTI masih tersamar dan belum bisa menunjuk pada entitas tertentu dalam masyarakat Indonesia yang diakui ada dan setara, dan bisa diangkakan secara jelas. Selain fakta stigma negatif yang masih cukup kuat, perbedaan metodologis dalam memperkirakan secara kuantitatif komunitas LGBTI juga masih menjadi kendala. Program HIV dan AIDS yang memiliki perangkat perkiraan angka, juga masih belum mampu memetakan secara jelas komunitas LGBTI, karena membatasi diri pada faktor perilaku berisiko yang berimplikasi pada tumpang tindih antara perilaku dan orientasi seksual, dan juga meminggirkan komunitas lesbian dan interseks. Pengakuan hak seksual sebagai hak asasi manusia adalah sebuah situasi yang digadang-gadang mewujud dalam konteks internasional maupun hukum dan aturan perundangan nasional. Turunannya, adalah situasi struktur pengampu kebijakan negara yang mampu memenuhi, menghargai dan melindungi hak sipil dan ekosob bagi komunitas LGBTI. Namun sejauh ini kedaulatan atas nama kehendak rakyat yang banyak tetap menjadi pertimbangan, sistem Norma budaya di Indonesia tentunya tidak akan melanggengkan keinginan dan tuntutan tersebut. "Akankah Gender ke Tiga" kemudian dapat diterima sebagai sesuatu yang lazim, atau justru sebaliknya yang terjadi adalah Tranphobia terhadap apapun namanya "Sebuahn Dunia Baru".

\section{DAFTAR PUSTAKA}

Ahmad Ramali dan K.S.T. Pamoenntjak, Kamus Kedokteran Cet XVI (Jakarta: tp, 1989). 205.

Ariyanto dan Rido Triawan, Jadi Kau Tidak Merasa Bersalah?! Studi Kasus Diskriminasi dan Kekerasan Terhadap LGBTI, Arus Pelangi, Jakarta, 2008.

Centre for Human Rights, National Institutions for the Promotion and 
Protection of Human Rights, Fact Sheet No. 19, Geneva, 1993.

Carlos F. Cáceres, Mario Pecheny, Tim Frasca and Roger Raupp Rios, Review of Legal Framework and the Situation of Human Rights Related to Sexual Diversity in Low and Middle Income Countries, UNAIDS, 2009.

Gunawan Kosasih, Hermaprhoditisma Cermin Kedokteran Majalah Tri Wulan (tk: PT Kalbe Farma, tt).

Jatmiko Gunawan, Persepsi Masyarakat terhadap Pengadilan. Master thesis, Program Pascasarjana Universitas Diponegoro, 1998.

Jeffrey Weeks, Sexuality, Routledge, 1986. Leonore Tiefer, "The Emerging Global Discourse of Sexual Rights", Journal of Sex \& Marital Therapy, BrunnerRoutledge, 28, 2002.

Mahjuddin, Masailul Fiqhiyah Berbagai Kasus yang Dihadapi Hukum Islam Masa Kini (Jakarta: Kalam Mulia, 2005).
Mansour Fakih, Analisis Gender dan Transformasi Sosial, Pustaka Pelajar, Yogyakarta, 1996.

Mansour Fakih, Roem Topatimasang, \& Toto Rahardjo, Mengubah Kebijakan Publik, Insist Press, Yogyakarta, 2005.

http://news.detik.com/read/2014/11/23/085913 /2756437/10/tuntut-adanya-genderketiga-puluhan-waria-gelar-aksi-damaidi-hi

Transeksual dan Transgender, http://psikologi4u.blogspot.com/2008/08 /transeksual-dan- transgender

Fenomena Transgender dan Hukum Operasi Kelamin, http://mdakwatuna.com/fenomenatransgender-dan-hukum-operasi-kelamin/ 